\title{
PERBANDINGAN SMT, JIT, DAN TOC DALAM LINGKUNGAN INDUSTRI SINGLE PRODUCT FLOW SHOP MENGGUNAKAN SIMAN ARENA
}

\author{
Eriana Astuty \\ Fakultas Bisnis dan Manajemen \\ Universitas Widyatama \\ Jl. Cikutra 204A Bandung 40125 \\ eriana.astuty@widyatama.ac.id
}

\begin{abstract}
ABSTRAK
Penelitian ini menguji 3 (tiga) sistem manufaktur, yaitu sistem manufaktur tradisional, just in time, dan theory of constraints dalam lingkungan industri single product flow shop yang mempunyai lintasan seri dimana ketiga sistem manufaktur dipengaruhi variasi total inventory buffer dan waktu proses yang berbeda sesuai dengan filosofi dari masing-masing sistem. Adapun tujuannya untuk mengukur dan menganalisa performansi, melihat ada/tidaknya pengaruh sistem manufaktur, variasi total inventory buffer serta interaksi keduanya terhadap performansi flowtime dan throughput. Penulis menggunakan Simulation Manufacturing ARENA untuk menguji sistem nyata keadaan lingkungan industri yang dicobakan ke dalam model tiruan simulasi komputer. Di akhir penelitian ini terbukti bahwa jenis sistem manufaktur, variasi total inventory buffer, dan interaksi keduanya ternyata mempengaruhi besarnya performansi nilai rata-rata flowtime dan throughput yang dihasilkan dari masing-masing sistem yang dicobakan. Simpulan terakhir adalah filosofi SMT tidaklah memberikan keuntungan yang lebih jika dibandingkan JIT dan TOC. Selanjutnya TOC mempunyai performansi di atas SMT dan JIT pada performansi rata-rata troughput, walaupun kadang-kadang TOC mempunyai rata-rata flowtime yang lebih tinggi dari SMT dan JIT, yang mana hal ini sebenarnya menjadi atribut bahwa TOC membutuhkan lebih sedikit inventory dibandingkan dengan sistem manufaktur lainnya.
\end{abstract}

Kata kunci: Sistem Manufaktur Tradisional, Just In Time, Theory Of Constraints, Inventory Buffer, Performansi

\section{PENDAHULUAN}

Di dalam industri manufaktur kita mengenal adanya Sistem Manufaktur Tradisional, Just In Time, Theory of Constrains dimana masing-masing sistem ini akan memberikan performansi yang berbeda-beda terhadap proses produksi yang dilakukan dalam lingkungan industri manufaktur tersebut.

Penelitian ini berupaya untuk mengukur dan menganalisa masing-masing performansi yang ditimbulkan dari ketiga sistem manufaktur diatas yang dipengaruhi oleh variasi total inventory buffer pada masing-masing sistem manufaktur, apabila ketiganya diterapkan dalam lingkungan industri single product flow shop pada lintasan produksi secara seri, sehingga dapat diketahui sistem manufaktur mana yang lebih baik diterapkan dalam keadaan lingkungan industri seperti di atas.

Akibat dari kompleksnya masalah yang terjadi pada sistem manufaktur, maka agar penelitian ini dapat dilaksanakan lebih terarah sesuai dengan tujuan, perlu ditetapkan batasan-batasan sebagai berikut:

1. Data dalam penelitian ini dibangkitkan melalui simulasi komputer dengan menggunakan Software Simulation Manufacturing ARENA

2. Sistem manufaktur yang digunakan untuk diujicobakan dalam lingkungan industri single product flow shop adalah Sistem Manufaktur Tradisional, Just In Time, Theory of Constrains.

3. Model proses manufaktur pada ke-3 sistem adalah finite queue flow shop

4. Sistem terdiri atas 5 stasiun kerja dan tiap mesin dalam stasiun kerja tidak mengalami breakdowns machine. 
5. Urutan proses mengikuti aturan prioritas First In First Out (FIFO)

6. Suplai bahan baku diasumsikan selalu tersedia

7. Produk yang dihasilkan dari sistem merupakan 1 tipe produk

8. Waktu setup adalah nol, hal ini dikarenakan sistem hanya menghasilkan 1 macam produk sehingga tidak memerlukan setup mesin.

9. Total buffer inventory pada tiga sistem di-set yaitu 4, 8, 12, 16 unit buffer, dimana tiap stasiun kerja pada Sistem Manufaktur Tradisional dan JIT mempunyai kapasitas buffer yang sama.

10. Penelitian ini tidak memperhitungkan scrapt maupun rework

Sehingga dengan adanya penelitian ini diharapkan bisa menjawab dua pertanyaan utama yang timbul, yaitu :

1. Bagaimana pengaruh yang ditimbulkan oleh sistem manufaktur yang digunakan pada keadaan lingkungan industri di atas, serta pengaruh dari variasi total inventory buffer yang diterapkam ke dalam masing-masing sistem manufaktur tersebut terhadap performansi sistem yaitu rata-rata flowtime dan rata-rata throughput dari sistem.

2. Sistem manufaktur mana yang paling tepat diterapkan untuk keadaan lingkungan industri seperti di atas

\section{LANDASAN TEORI}

\section{A. Sistem Manufaktur Tradisional}

Perkembangan komputer era 50-an mengantarkan bisnis pengolahan informasi dengan implikasinya yang turut membentuk perubahan teknik-teknik pengolahan data dan operasinya. Tidak satupun bidang yang terlepas dari impact perkembangan komputer, termasuk bidang manufaktur. Metoda-metoda tradisional ini dibuat berdasarkan asumsi-asumsinya tentang keadaan yang sudah ditentukan (kadang-kadang malah tidak realistik). Metoda-metoda ini berlaku sebagai alat bantu perencanaan logistik saja, bahkan kadang-kadang memaksakan penerapan suatu konsep ke dalam realitas agar dapat digunakan. Terobosan dalam bidang manajemen persediaan terjadi secara radikal. Metoda baru yang dibuat dengan mengandalkan kemampuan komputer adalah sistem MRP (Material Requirement Planning).

\section{B. Sistem Manufaktur Just In Time (JIT)}

Sistem produksi Jepang ini dikenal dengan sistem produksi tepat waktu (Just In Time). Filosofi dari sistem produksi Jepang (JIT) adalah memperkecil kemubaziran (Eliminate of Waste). Bentuk kemubaziran antara lain adalah :

1. Kemubaziran dalam waktu

2. Kemubaziran dalam material

3. Kemubaziran dalam manajemen

Jepang melakukan Eliminate of Waste karena Jepang tidak mempunyai resources yang cukup. Jadi setiap melakukan pengambilan keputusan terutama untuk masalah produksi selalu menganut pada prinsip efisiensi, efektivitas, dan produktivitas.

Untuk dapat melaksanakan eliminate of waste, Jepang melakukan strategi sebagai berikut :

1. Hanya memproduksi jenis produksi yang diperlukan

2. Hanya memproduksi produk se-jumlah yang dibutuhkan

3. Hanya memproduksi produk pada saat diperlukan

Tujuan utama dari sistem produksi JIT adalah untuk dapat memproduksi produk dengan kualitas (quality) yang terbaik, ongkos (cost) termurah, dan pengiriman (delivery) pada saat yang tepat, disingkat QCD. Tujuan utama ini bisa dicapai jika ketiga unsur berikut dapat dilaksanakan secara terpadu yaitu melakukan pengendalian kuantitas dengan baik, melakukan pengendalian kualitas dengan baik, dan menjunjung tinggi harkat kemanusiaan karyawan 


\section{Sistem Manufaktur Theory Of Contraints (TOC)}

TOC atau dikenal juga sebagai OPT merupakan sistem perencanaan dan pengendalian prouksi yang relatif baru, dikembangkan oleh Eliyahu M. Goldratt pada tahun 1980. Beberapa kalangan akademik maupun praktisi, masing-masing memiliki pandangan tentang OPT. Vollman (1986) memandang OPT sebagai perbaikan dari MRP II. Lundrigan (1986) mengatakan OPT sebagai JIT versi barat. Swann (1988) menyarankan OPT digunakan sebagai alat yang dipakai bersama MRP. Walaupun ada berbagai pandangan tentang OPT, tetapi pada dasarnya ada kesamaan pendapat dalam logika pendekatan Goldratt yaitu OPT memfokuskan pada kendala-kendala yang ada (constraints).

\section{Buffer (penyangga)}

Efektivitas proses produksi akan mempengaruhi buffer sebagai persediaan penyangga, begitupun sebaliknya. Dalam hal ini buffer memiliki dua pengertian yaitu sebagai kapasitas antrian untuk menunggu proses berikutnya dan buffer sebagai komponen produk jadi (diperoleh dari sumber lain). Buffer dalam suatu proses produksi diperlukan keberadaannya karena input dan output dalam suatu stasiun kerja selalu berubah-ubah. Penempatan buffer yang baik menyebabkan tenaga kerja dan fasilitas menjadi produktif. Sedangkan kebutuhan buffer tergantung pada jenis operasi yang dilakukan pada suatu proses produksi. Jumlah persediaan buffer yang ekonomis ditentukan berdasarkan terkendali tidaknya aliran antara stasiun kerja. Walaupun dengan jumlah buffer yang besar dapat meningkatkan utilitas stasiun kerja atau mesin, namun hal ini juga akan berdampak :

1. Waktu silkus manufaktur yang panjang

2. Sistem control produksi yang mahal dan kompleks.

3. Biaya perpindahan material yang tinggi.

4. Kebutuhan ruang sebagai media penyimpanan

\section{E. Simulasi Komputer}

Emsoff (1970) mendefinisikan simulasi sebagai :

Suatu model sistem dimana komponen-komponennya direpresentasikan oleh proses-proses aritmatika dan logika yang dijalankan pada komputer untuk memperkirakan sifat-sifat dinamis sistem tersebut.

Jadi simulasi merupakan model tiruan dari sistem nyata. Titik tolak pemodelannya adalah penyederhanaan sistem nyata dengan hanya memperhatikan beberapa bagian atau sifat utama yang mempunyai hubungan sebagai akibat dari sistem yang sebenarnya. Dengan simulasi komputer, kita dapat melakukan berbagai kemungkinan percobaan tanpa takut mengalami kegagalan, dibandingkan jika percobaan tersebut dilakukan pada sistem nyata Keuntungan dengan melakukan simulasi antara lain:

1. Tidak semua sistem (terutama sistem yang komplek) dapat direpresentasikan dalam model matematik sehingga simulasi merupakan alternatif yang memungkinkan

2. Simulasi dapat mengestimasi performansi suatu sistem pada kondisi tertentu dan dapat memberikan alternatif desain yang terbaik berdasarkan spesifikasi yang diinginkan

3. Simulasi memungkinkan untuk melakukan percobaan terhadap sistem tanpa adanya resiko pada sistem nyata

4. Simulasi memungkinkan untuk melakukan studi suatu sistem jangka panjang dalam waktu yang relatif singkat

Kelemahan dalam melakukan simulasi antara lain:

1. Simulasi hanya mengestimasi karakteristik sistem nyata berdasarkan masukan tertentu

2. Harga model simulasi relatif mahal dan memerlukan waktu yang cukup banyak untuk pengembangannya

3. Kualitas dan analisis model tergantung pada keahlian si pembuat model 
Karakteristik Model Simulasi (sember: Emsoff 1970, hal 11-13):

1. Mampu melakukan penggambaran sistem yang statis maupun dinamis

2. Dapat dibuat umum (menyeluruh) ataupun rinci tergantung kompleksitas sistem nyata

3. Dapat memodelkan sistem fisik maupun tingkah laku

4. Mekanisme prosedur simulasi dapat dilakukan menyeluruh ataupun sebagian

5. Model simulasi yang dilakuakan bisa berulang (repetisi) ataupun kesetimbangan (hasil diambil apabila sistem nyata yang dimodelkan telah mencapai titik seimbang/stabil)

Metodologi Simulasi Komputer (sumber: Law 1990, hal 47)

1. Penentuan formulasi masalah dan perencanaan penelitian

2. Mengumpulkan data dan perancangan model

3. Validasi model

4. Penyusunan program komputer dan verifikasi

5. Uji program

6. Validasi program

7. Perancangan eksperimen

8. Mengeksekusi program

9. Analisis hasil simulasi

10. Dokumentasi, presentasi, dan implementasi hasil

\section{Simulation Manufacturing ARENA}

ARENA adalah paket simulasi general-purpose yang memiliki kemampuan untuk memodelkan sistem manufaktur (seperti flowlines, assembly lines, job shop, AS/RS warehousing, for trucks, Automated Guided Vehicles (AGV), conveyors) dan sistem non manufaktur (seperti paper flow, health care, maintenance system, computer networks, retail \& restaurants facilities, transportation \& logistic system, business process reengineering $(B P R)$ dan lain-lain.

\section{Analisis Statistik dalam ARENA}

1. ARENA dilengkapi dengan kemampuan untuk melakukan uji distribusi dari waktu proses, waktu antar kerusakan mesin, loading/unloading time yang akan digunakan sebagai input ke dalam model simulasi. Untuk menguji distribusi dari data statistik digunakan input processor.

2. ARENA juga mampu me-generate suatu distribusi. Analisis statistik yang digunakan untuk output simulasi dibagi menjadi 5 jenis yaitu:

a. Time Persistent Statistic digunakan untuk mencatat sample mean, coefficient of variation, minimum, maximum, dan final value.

b. Tally Statistics digunakan untuk memperoleh observational statistic. Meliputi nilainilai sample mean, coefficient of variation, minimum, maximum, dan jumlah observasi.

c. Counter digunakan untuk memperoleh count-based statistics. Contohnya untuk menghitung jumlah produk yang selesai diproses.

d. Output mendefinisikan semua EXPRESSION dimana nilai-nilainya akan dicatat dalam summary report pada setiap replikasi.

e. Frequencies digunakan untuk mencatat frekuensi terjadinya variabel dari time persistent atau expression

\section{METODOLOGI PENELITIAN}

\section{A. Desain Penelitian}

1. Stasiun kerja dan waktu proses dari tiga sistem manufaktur

Obyek penelitian untuk mengukur pengaruh total inventory buffer dan pengaruh waktu proses terhadap ketiga sistem manufaktur yang diujicobakan (yaitu 
tradisional, just in time, dan theory of constraints) dimana masing-masing sistem manufaktur mempunyai 5 stasiun kerja adalah sebagai berikut:

\section{Sistem Manufaktur tradisional}

Setiap mesin memiliki waktu proses yang menpunyai proporsi waktu proses yang sama (masing-masing proporsi waktu proses sebesar 1/3), yaitu :

Tabel 1. Waktu proses sistem manufaktur tradisional

\begin{tabular}{|c|c|}
\hline $\begin{array}{c}\text { Stasiun } \\
\text { Kerja }\end{array}$ & $\begin{array}{c}\text { Waktu proses } \\
\text { (Tiap SK mempunyai proporsi sebesar 1/3 }\end{array}$ \\
\hline I & $1 / 3$ sebesar 15 menit, 1/3 sebesar 20 menit, 1/3 sebesar 25 menit \\
\hline II & $1 / 3$ sebesar 15 menit, 1/3 sebesar 20 menit, 1/3 sebesar 25 menit \\
\hline III & $1 / 3$ sebesar 15 menit, 1/3 sebesar 20 menit, 1/3 sebesar 25 menit \\
\hline IV & $1 / 3$ sebesar 15 menit, 1/3 sebesar 20 menit, 1/3 sebesar 25 menit \\
\hline V & $1 / 3$ sebesar 15 menit, 1/3 sebesar 20 menit, 1/3 sebesar 25 menit \\
\hline
\end{tabular}

\section{Sistem manufaktur Just In Time}

Sesuai dengan filosofi JIT, variasi waktu proses yang terjadi pada masing-masing stasiun kerja haruslah dikurangi, sehingga akan lebih menyeimbangkan lini produksi yang ada

Tabel 2. Waktu proses sistem manufaktur just in time

\begin{tabular}{|c|l|}
\hline $\begin{array}{c}\text { Stasiun } \\
\text { Kerja }\end{array}$ & \multicolumn{1}{c|}{ Waktu proses } \\
\hline I & $10 \%=15$ menit, $80 \%=20$ menit, $10 \%=25$ menit \\
\hline II & $10 \%=15$ menit, $80 \%=20$ menit, $10 \%=25$ menit \\
\hline III & $10 \%=15$ menit, $80 \%=20$ menit, $10 \%=25$ menit \\
\hline IV & $10 \%=15$ menit, $80 \%=20$ menit, $10 \%=25$ menit \\
\hline V & $10 \%=15$ menit, $80 \%=20$ menit, $10 \%=25$ menit \\
\hline
\end{tabular}

\section{Sistem manufaktur Theory of Constraints}

Pada sistem manufaktur TOC ini, eksperimen akan lebih difokuskan pada stasiun kerja yang berkendala (constraining workstation).

Pada constraining workstation ini akan diletakkan sebuah buffer (dalam penelitian ini station kerja ke-5) sementara stasiun kerja-stasiun kerja lainnya tidak berkendala (non constraining workstation) dan tidak menggunakan buffer penyangga. Adapun pengaturan-pengaturan waktu proses untuk masing-masing stasiun kerja adalah sebagai berikut :

TOC-Constraining workstation (stasiun kerja ke-5)

Tabel 3. Waktu proses sistem manufaktur TOC

\begin{tabular}{|c|c|}
\hline $\begin{array}{c}\text { Stasiun } \\
\text { Kerja }\end{array}$ & Waktu proses \\
\hline V & $20 \%=15$ menit, $60 \%=20$ menit, $20 \%=25$ menit \\
\hline
\end{tabular}

\section{TOC-non constraining workstation (stasiun kerja ke-1,2,3,4)}

Sementara pada Non constraining workstation, aturan waktu proses dikakukan berdasarkan pada tingkat inventory pada buffer kendala (di depan stasiun ke-5)

\section{Buffer inventory dibagi atas 3:}

a. Jika inventory pada buffer di stasiun kerja yang berkendala (stasiun kerja ke-5) terdiri atas $\leq$ 1/3 dari kapasitas ukuran buffer, maka waktu proses pada masing-masing stasiun kerja yang tidak berkendala (Non Constraining workstation) adalah sebesar 15 menit. 
b. Jika inventory pada buffer di stasiun kerja yang berkendala (stasiun kerja ke-5) terdiri atas 1/3 < kapasitas ukuran buffer $\leq \mathbf{2 / 3}$, maka waktu proses pada masing-masing stasiun kerja yang tidak berkendala (non constraining workstation) adalah 50\% sebesar 15 menit, dan 50\% sebesar 20 menit.

c. Jika inventory pada buffer di stasiun kerja yang berkendala (stasiun kerja ke-5) terdiri atas > 2/3 dari kapasitas ukuran buffer, maka waktu proses pada masing-masing stasiun kerja yang tidak berkendala (non constraining workstation) ) adalah $1 / 3$ sebesar 15 menit, $1 / 3$ sebesar 20 menit, serta $1 / 3$ sebesar 25 menit

Tabel 4. Waktu proses sistem manufaktur TOC

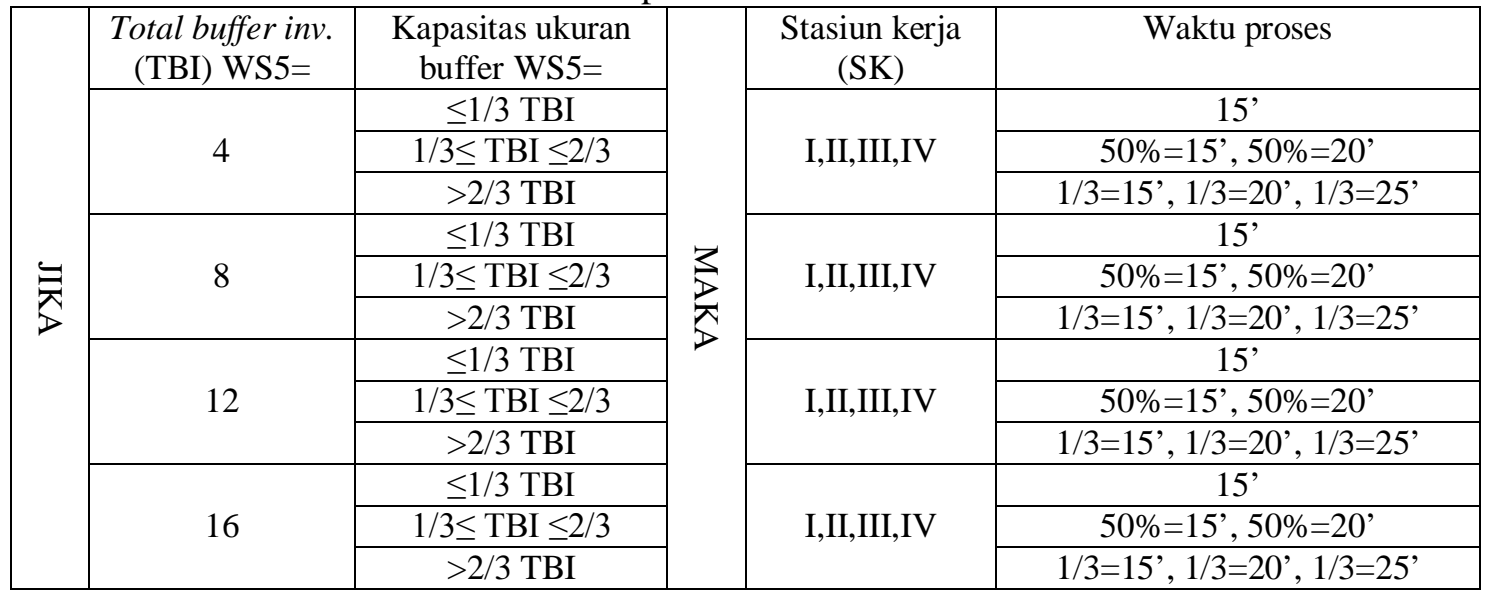

2. Stasiun kerja dan konfigurasi penempatan buffer di ketiga sistem manufaktur Stasiun Kerja Sistem Manufaktur Tradisional

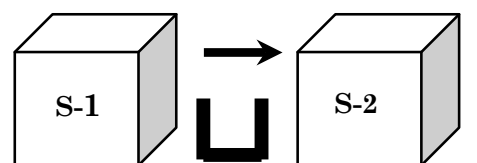

b-1

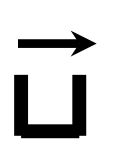

b-2

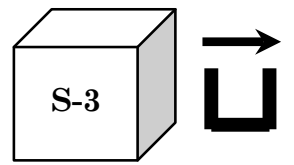

b-3

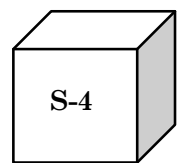

Gambar 1. Sistem manufaktur tradisional dengan 5 stasiun kerja

Stasiun Kerja Sistem Manufaktur Just In Time (JIT)

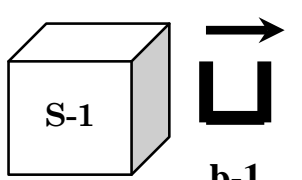

b-1
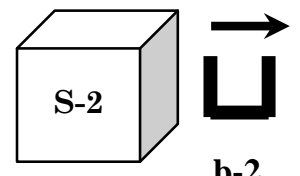

b-2

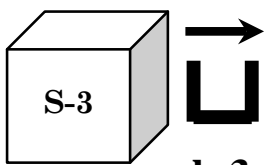

b-3

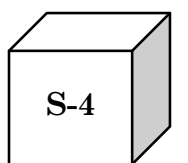

b-4 b-4

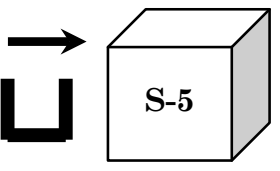

Gambar 2. Sistem manufaktur JIT dengan 5 stasiun kerja 
Stasiun Kerja Sistem Manufaktur Theory Of Constraints (TOC)

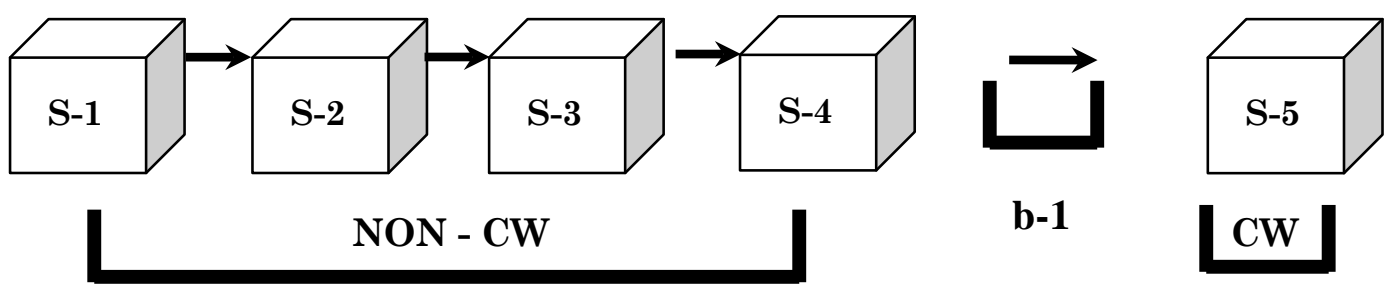

Gambar 3. Sistem manufaktur TOC dengan 5 stasiun kerja

Keterangan:

S-1: Stasiun Kerja I

S-2: Stasiun Kerja II

S-3: Stasiun Kerja III

S-4: Stasiun Kerja IV

S-5: stasiun Kerja V b-1: buffer yang ditempatkan untuk S-2

b-2: buffer yang ditempatkan untuk S-3

b-3: buffer yang ditempatkan untuk S-4

b-4: buffer yang ditempatkan untuk S-5

CW : Constraining Workstation

\section{Konfigurasi Penempatan Buffer}

Tabel 5 Konfigurasi penempatan buffer untuk SMT dan JIT

\begin{tabular}{|c|c|c|c|c|}
\hline \multirow{2}{*}{ Total Inventory Buffer } & \multicolumn{4}{|c|}{ Alternatif penempatan buffer di ......... } \\
\cline { 2 - 5 } & b-1 & b-2 & b-3 & b-4 \\
\hline 4 & 1 & 1 & 1 & 1 \\
\hline 8 & 2 & 2 & 2 & 2 \\
\hline 12 & 3 & 3 & 3 & 3 \\
\hline 16 & 4 & 4 & 4 & 4 \\
\hline
\end{tabular}

Tabel 6. Konfigurasi penempatan buffer untuk TOC

\begin{tabular}{|c|c|}
\hline Total Inventory Buffer & Alternatif penempatan buffer di: \\
\cline { 2 - 2 } & b-1 \\
\hline 4 & 1 \\
\hline 8 & 2 \\
\hline 12 & 3 \\
\hline 16 & 4 \\
\hline
\end{tabular}

\section{B. Prosedur Penelitian}

Adapun prosedur penelitian yang dilakukan oleh penulis adalah sebagai berikut :

\section{Penetapan Tujuan Penelitian}

Berdasarkan latar belakang penelitian, maka penulis menetapkan tujuan dari penelitian ini adalah untuk mengukur, membandingkan, dan menganalisa performansi dari ketiga sistem manufaktur yang diujikan yaitu sistem manufaktur tradisional, Just In Time, dan Theory of Constraints dengan segala filosofinya, dalam lingkungan single product flow shop pada lintasan produksi secara seri. Adapun performansi yang menjadi alat ukur perbandingannya adalah rata-rata flowtime dan rata-rata throughput dari sistem.

\section{Studi pustaka}

Dalam proses ini, penulis mempelajari teori-teori dasar dan karakteristik dari masing-masing sistem manufaktur yang diujicobakan, yaitu mempelajari teori dari Sistem Manufaktur Tradisional, JIT dan TOC. Selain itu pula penulis juga mempelajari simulasi komputer dengan menggunakan Software Simulation Manufacturing ARENA serta jurnal-jurnal dan referensi yang menunjang penulisan ini. 


\section{Penetapan Variabel}

Variabel yang digunakan dan berpengaruh dalam ketiga sistem manufaktur diatas adalah :

1. Jumlah stasiun kerja (mesin) pada ketiga sistem manufaktur adalah 5 stasiun kerja.

2. Waktu proses yang berlangsung selama sistem berjalan untuk masing-masing sistem manufaktur mempunyai aturan waktu proses yang berbeda-beda sesuai dengan filosofi dari masing-masing sistem manufaktur

3. Ukuran inventory buffer

Buffer (penyangga) diperlukan untuk menjaga agar proses produksi tetap berlangsung. Dalam hal ini, total inventory buffer adalah sama untuk tiap stasiun kerja pada masing-masing kondisi penelitian.

4. Waktu antar kedatangan

Sesuai dengan waktu proses untuk stasiun kerja ke-2, ke-3, ke-4, ke-5, Sedangkan untuk stasiun kerja ke-1 waktu antar kedatangan sama dengan waktu proses pada mesin ke-1 dan supply material selalu tersedia (mesin ke-1 tidak pernah mengalami starving)

5. Lama waktu replikasi simulasi yaitu 100000 menit

6. Jumlah replikasi (pengulangan) simulasi untuk satu kondisi penelitian dilakukan sebanyak 10 replikasi

\section{Penetapan kondisi penelitian}

1. Masing-masing sistem manufaktur terdiri atas 5 stasiun kerja yang disusun secara seri.

2. Total inventory buffer yang digunakan pada masing-masing sistem manufaktur adalah sama yaitu 4, 8, 12, 16 unit, dimana ukuran buffer adalah sama untuk tiap stasiun kerja.

3. Waktu proses pada masing-masing sistem manufaktur berbeda-beda, sesuai filosofi dari masing-masing sistem manufaktur yang digunakan.

4. Jumlah kondisi simulasi untuk ketiga sistem manufaktur yang diujicobakan adalah : masing-masing sistem manufaktur mempunyai 4 konfigurasi total ukuran buffer inventory sehingga secara keseluruhan jumlah kondisi simulasi adalah 12 kondisi.

\section{Pembuatan model simulasi}

Model simulasi untuk ketiga jenis sistem manufaktur yang akan diujicobakan dibuat dengan bantuan Software Simulation Manufacturing ARENA 


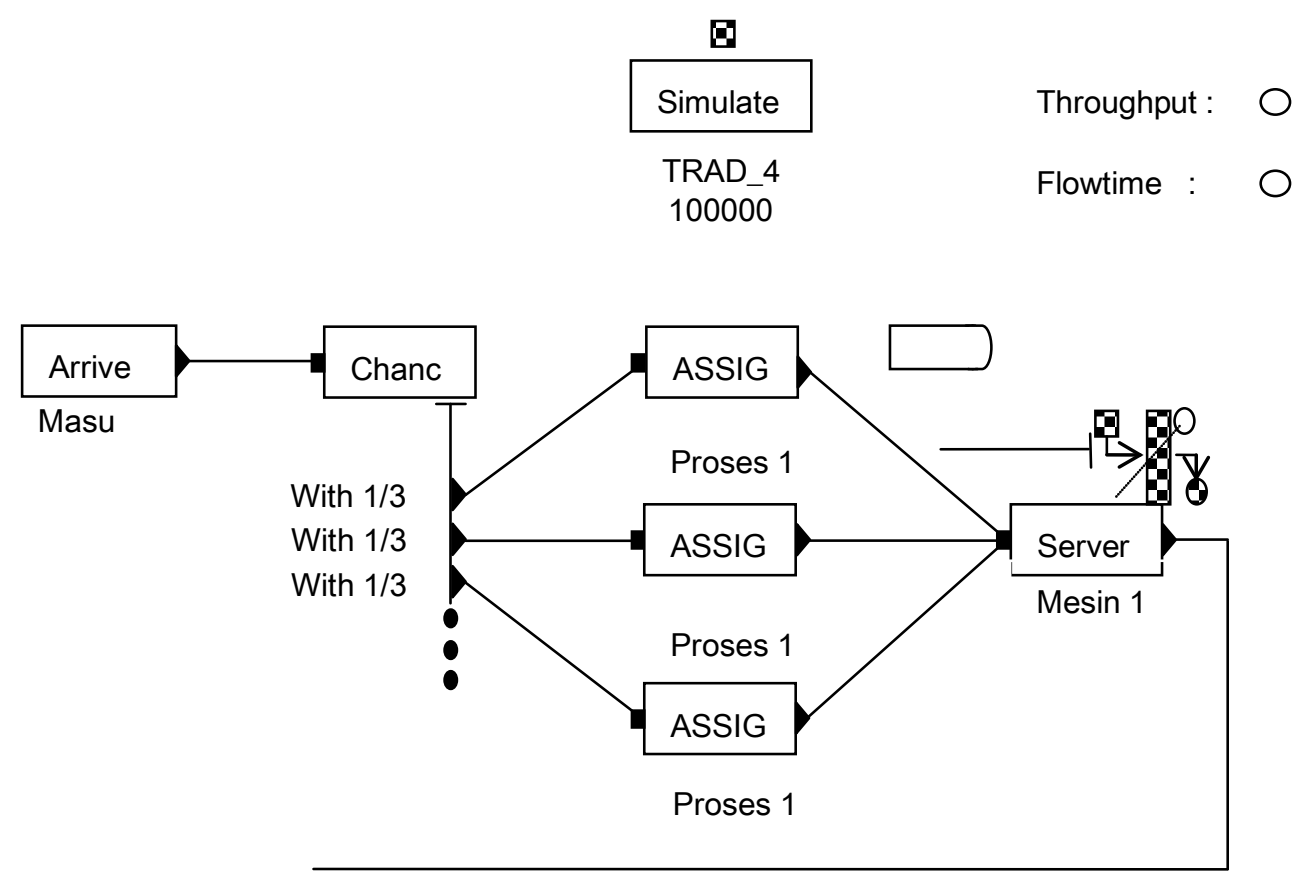

(model simulasi sama untuk mesin ke-2, mesin ke-3, dan mesin ke-4)

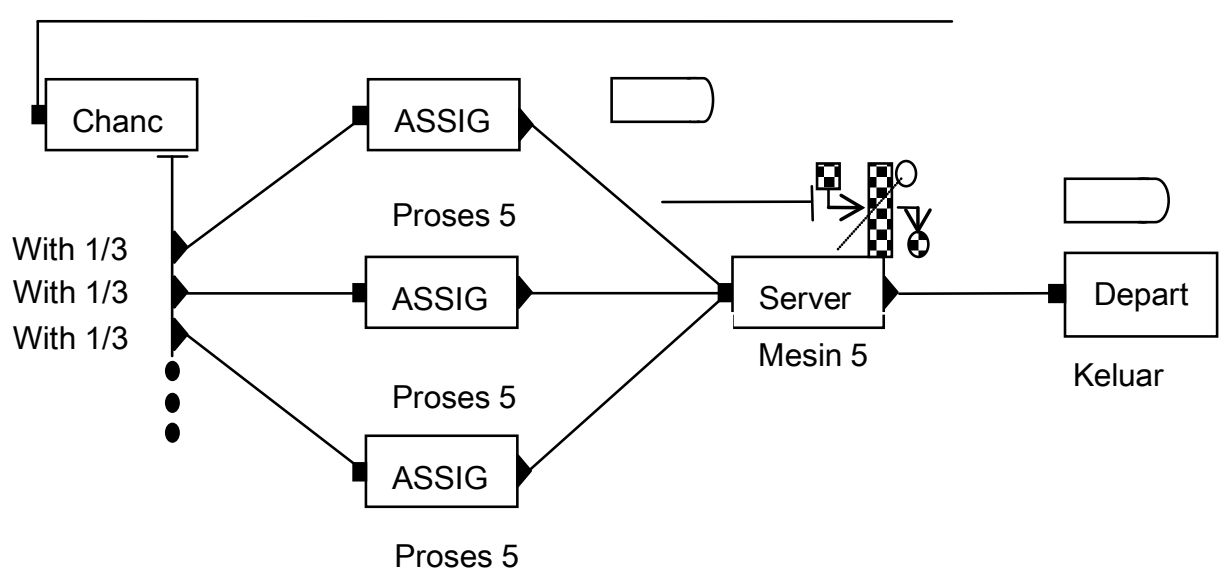

Gambar 4. Pemodelan SIMAN ARENA SMT (untuk JIT dan TOC tidak dilampirkan)

\section{Pengoperasian model}

Setelah model simulasi untuk masing-masing sistem manufaktur dibuat, dilakukan proses verifikasi pada model untuk menguji apakah model bekerja sesuai dengan yang diinginkan dan tidak mengandung kesalahan, baik kesalahan syntax maupun kesalahan logika. Selain itu pula pada model simulasi dari ketiga sistem manufaktur diatas juga dilakukan proses validasi yang bertujuan untuk menguji apakah model yang dibuat sudah mempresentasikan sistem nyata yang diinginkan. Kedua pengujian diatas dimaksudkan agar proses pengoperasian model akan menghasilkan keluaran (output) simulasi yang benar-benar valid dan akurat 


\section{Pengukuran performansi}

Performansi yang digunakan sebagai alat ukur dari ketiga sistem manufaktur yang diujicobakan dalam lingkungan single product flow shop pada lintasan produksi secara seri adalah :

Rata-rata flowtime yaitu lamanya waktu yang dibutuhkan oleh suatu entiti mulai dari memasuki sistem manufaktur sampai keluar dari sistem manufaktur tersebut.

Throughput yaitu banyaknya produk akhir yang berhasil dikerjakan oleh sistem dalam suatu satuan waktu tertentu

\section{Analisis}

Hasil keluaran simulasi menghasilkan data keluaran berupa flowtime dan throughput sistem sebanyak 10 (sepuluh) data keluaran perkondisi, maka perhitungan statistik yang dilakukan adalah sebagai berikut :

a. Perhitungan untuk harga rata-rata (mean) untuk berbagai alternatif kondisi pada masing-masing sistem manufaktur, yaitu :

$$
X=\frac{X i}{n}
$$

b. Menabelkan perhitungan (a) untuk berbagai alternatif kondisi pada masingmasing sistem manufaktur.

c. Mem-plot data (b) pada grafik

d. Menganalisis hasil simulasi dengan analisis variansi

Adapun tujuan utama penggunaan analisis variansi dalam penelitian ini adalah untuk menganalisis serta menguraikan seluruh variasi yang terjadi atas bagianbagian yang mempunyai makna, dalam hal ini menguji, apakah terdapat variasi dalam pengamatan yang diakibatkan oleh perbedaan dalam perlakuan. Keluaran simulasi penelitian diukur dengan flowtime dan throughput sistem. Di dalam meneliti dan menganalisis hasil simulasi, penulis menggunakan analisis variansi dwifaktor karena menggunakan dua faktor utama yang diduga mempunyai pengaruh terhadap ukuran performansi yaitu sistem manufaktur dan total inventory buffer. Sehingga didefinisikan untuk penelitian ini bahwa faktor-faktor pada analisis variansi yaitu :

1. Faktor A : Sistem manufaktur

2. Faktor B : Total inventory buffer

Setiap faktor terdiri atas beberapa taraf (level). Taraf pada faktor dimaksudkan untuk menentukan apakah perbedaan antara masing-masing keluaran simulasi (sampel) hanyalah sebagai variasi acak saja ataukah memang taraf-taraf tersebut mempengaruhi performansi yang diteliti. Penentuan taraf didasarkan atas banyaknya perlakuan yang diberikan. Untuk faktor A terdiri dari 3 taraf dan faktor $\mathrm{B}$ terdiri atas 4 taraf.

1. Taraf pada faktor A

Sistem manufaktur tradisional (SMT), Sistem manufaktur Just In Time (JIT), Sistem manufaktur Theory Of Constrains (TOC)

2. Taraf pada faktor $B$

Total inventory buffer $=4($ buffer size $=4)$

Total inventory buffer $=8($ buffer size $=8)$

Total inventory buffer $=12$ (buffer size $=12)$

Total inventory buffer $=16$ (buffer size $=16)$

\section{Langkah-langkah Analisis Variansi Dwifaktor Langkah ke-1}


Kelompokkan output (hasil) simulasi ke dalam tabel. Bari tabel sebagai faktor A dan kolom tabel sebagai faktor B.

Tabel 7. Percobaan dwifaktor dengan n replikasi

\begin{tabular}{|c|c|c|c|c|c|}
\hline \multirow{2}{*}{\multicolumn{2}{|c|}{ Jenis sistem manufaktur }} & \multicolumn{4}{|c|}{ Perlakuan } \\
\hline & & \multirow{2}{*}{$\begin{array}{c}\begin{array}{c}\text { Buffer } \\
\text { size }=\mathbf{4}\end{array} \\
\text { Y1 11 }\end{array}$} & \multirow{2}{*}{$\begin{array}{c}\begin{array}{c}\text { Buffer } \\
\text { size }=\mathbf{8}\end{array} \\
\text { Y1 21 }\end{array}$} & \multirow{2}{*}{$\begin{array}{c}\text { Buffer size } \\
\text { = 12 } \\
\text { Y1 } 31\end{array}$} & \multirow{2}{*}{$\begin{array}{c}\begin{array}{c}\text { Buffer size } \\
\text { = 16 }\end{array} \\
\text { Y1 } 41\end{array}$} \\
\hline \multirow{5}{*}{ SMT } & Rep - 1 & & & & \\
\hline & Rep - 2 & Y1 12 & Y1 22 & Y1 32 & Y1 42 \\
\hline & Rep -3 & Y1 13 & Y1 23 & Y1 33 & Y1 43 \\
\hline & $\ldots \ldots$ & $\ldots \ldots$ & $\ldots \ldots$ & $\ldots \ldots$ & $\ldots \ldots$ \\
\hline & Rep - 10 & Y1 110 & Y1 210 & Y1 310 & Y1 410 \\
\hline \multirow{5}{*}{ JIT } & Rep - 1 & Y2 11 & Y2 21 & Y2 31 & Y2 41 \\
\hline & Rep - 2 & Y2 12 & Y2 22 & Y2 32 & Y2 42 \\
\hline & Rep - 3 & Y2 13 & Y2 23 & Y2 33 & Y2 43 \\
\hline & $\ldots \ldots$ & & & & \\
\hline & Rep - 10 & Y2 110 & Y2 210 & Y2 310 & Y2 410 \\
\hline \multirow{5}{*}{ TOC } & Rep -1 & Y3 11 & Y3 21 & Y3 31 & Y3 41 \\
\hline & Rep - 2 & Y3 12 & Y3 22 & Y3 32 & Y3 42 \\
\hline & Rep - 3 & Y3 13 & Y3 23 & Y3 33 & Y3 43 \\
\hline & $\ldots \ldots$ & & & & \\
\hline & Rep - 10 & Y3 110 & Y3 210 & Y3 310 & Y3 410 \\
\hline
\end{tabular}

\section{Langkah ke-2}

Lakukan perhitungan untuk setiap faktor B untuk sistem manufaktur (baris tabel), penjumlahan dilakukan untuk setiap harga keluaran simulasi, nilai rata-rata dan variansinya.

Count $_{i} \quad$ : Jumlah replikasi

Sum $_{i} \quad:$ Y.11 + Y.12 + ... Y.110

Avg $_{i} \quad:$ Sum $i+$ Count $i$

$\operatorname{Var}_{i} \quad:\left(\mathrm{Y} .11-\text { Avg }_{i}\right)^{2}+\left(\mathrm{Y} .12-\text { Avg }_{i}\right)^{2}+\ldots+\left(\mathrm{Y} .110-\text { Avg }_{i}\right)^{2}:\left(\right.$ Count $\left._{i}-1\right)$

Sehingga tabel 7 dapat diringkas sebagai berikut :

Tabel 8. Penjumlahan faktor B : SMT

\begin{tabular}{|c|c|c|c|c|c|}
\hline SMT & BS = 4 & BS = 8 & BS = 12 & BS = 16 & Total \\
\hline Count & $\mathrm{n}_{11 .}$ & $\mathrm{n}_{12 .}$ & $\mathrm{n}_{13 .}$ & $\mathrm{n}_{14 .}$ & $\mathrm{n}_{1.1}$ \\
\hline Sum & $\mathrm{T}_{11 .}$ & $\mathrm{T}_{12 .}$ & $\mathrm{T}_{13 .}$ & $\mathrm{T}_{14 .}$ & $\mathrm{T}_{1.1}$ \\
\hline Avg & $\mathrm{Y}_{11 .}$ & $\mathrm{Y}_{12 .}$ & $\mathrm{Y}_{13 .}$ & $\mathrm{Y}_{14 .}$ & $\mathrm{Y}_{1.1}$ \\
\hline Var & $\mathrm{V}_{11 .}$ & $\mathrm{V}_{12 .}$ & $\mathrm{V}_{13 .}$ & $\mathrm{V}_{14 .}$ & $\mathrm{V}_{1.1}$ \\
\hline
\end{tabular}

Tabel 9. Penjumlahan faktor B : JIT

\begin{tabular}{|c|c|c|c|c|c|}
\hline JIT & BS = 4 & BS = 8 & BS = 12 & BS = 16 & Total \\
\hline Count & $\mathrm{n}_{21 .}$ & $\mathrm{n}_{22 .}$ & $\mathrm{n}_{23 .}$ & $\mathrm{n}_{24 .}$ & $\mathrm{n}_{2.1}$ \\
\hline Sum & $\mathrm{T}_{21 .}$ & $\mathrm{T}_{22 .}$ & $\mathrm{T}_{23 .}$ & $\mathrm{T}_{24 .}$ & $\mathrm{T}_{2.1}$ \\
\hline Avg & $\mathrm{Y}_{21 .}$ & $\mathrm{Y}_{22 .}$ & $\mathrm{Y}_{23 .}$ & $\mathrm{Y}_{24 .}$ & $\mathrm{Y}_{2.1}$ \\
\hline Var & $\mathrm{V}_{21 .}$ & $\mathrm{V}_{22 .}$ & $\mathrm{V}_{23 .}$ & $\mathrm{V}_{24 .}$ & $\mathrm{V}_{2.1}$ \\
\hline
\end{tabular}

Tabel 10. Penjumlahan faktor B : TOC

\begin{tabular}{|c|c|c|c|c|c|}
\hline TOC & BS $=\mathbf{4}$ & BS $=\mathbf{8}$ & BS = 12 & BS = 16 & Total \\
\hline Count & $\mathrm{n}_{31 .}$ & $\mathrm{n}_{32 .}$ & $\mathrm{n}_{33 .}$ & $\mathrm{n}_{34 .}$ & $\mathrm{n}_{3.1}$ \\
\hline Sum & $\mathrm{T}_{31 .}$ & $\mathrm{T}_{32 .}$ & $\mathrm{T}_{33 .}$ & $\mathrm{T}_{34 .}$ & $\mathrm{T}_{3.1}$ \\
\hline Avg & $\mathrm{Y}_{31 .}$ & $\mathrm{Y}_{32 .}$ & $\mathrm{Y}_{33 .}$ & $\mathrm{Y}_{34 .}$ & $\mathrm{Y}_{3.1}$ \\
\hline Var & $\mathrm{V}_{31 .}$ & $\mathrm{V}_{32 .}$ & $\mathrm{V}_{33 .}$ & $\mathrm{V}_{34 .}$ & $\mathrm{V}_{3.1}$ \\
\hline
\end{tabular}




\section{Langkah ke-3}

Lakukan perhitungan dari tabel 8,9, dan 10 ke dalam tabel 11:

Tabel 11. Penjumlahan Total faktor A

\begin{tabular}{|c|c|c|c|c|}
\hline Total & BS $=\mathbf{4}$ & BS $=\mathbf{8}$ & BS $=\mathbf{1 2}$ & BS = 16 \\
\hline Count & $\mathrm{n}_{1 .}$ & $\mathrm{n}_{2 .}$ & $\mathrm{n}_{3 .}$ & $\mathrm{n}_{4 .}$ \\
\hline Sum & $\mathrm{T}_{1 .}$ & $\mathrm{T}_{2 .}$ & $\mathrm{T}_{3 .}$ & $\mathrm{T}_{4 .}$ \\
\hline Avg & $\mathrm{Y}_{1 .}$ & $\mathrm{Y}_{2 .}$ & $\mathrm{Y}_{3 .}$ & $\mathrm{Y}_{4 .}$ \\
\hline Var & $\mathrm{V}_{1 .}$ & $\mathrm{V}_{2 .}$ & $\mathrm{V}_{3 .}$ & $\mathrm{V}_{4 .}$ \\
\hline
\end{tabular}

\section{Langkah ke-4}

Setelah tabel-tabel dibuat maka tentukan hiputesa yang akan diuji. Untuk notasi faktor maupun taraf sesuai dengan contoh yang telah diberikan sebelumnya.

H'0 $\quad: \alpha_{1}=\alpha_{2}=\ldots=\alpha_{3}=0$, pengaruh faktor A nol atau secara signifikan sistem manufaktur tidak berpengaruh atas performansi sistem.

H'0 $: \beta_{1}=\beta_{2}=\ldots=\beta_{3}=0$, pengaruh faktor $B$ nol atau secara signifikan ukuran buffer tidak berpengaruh atas performansi sistem

H','0 $\quad:(\alpha \beta)_{11}=(\alpha \beta)_{12}=.=(\alpha \beta)_{a b}=0$, interaksi faktor A dan B tidak ada.

$\mathrm{H}_{1}{ }_{1}$ : paling sedikit satu $\alpha_{\mathrm{i}}$ tidak sama dengan nol atau adanya faktor A yang berpengaruh pada performansi sistem

$\mathrm{H}{ }_{1} \quad$ : paling sedikit ada satu $\beta_{\mathrm{i}}$ tidak sama dengan nol atau adanya faktor $\mathrm{B}$ yang berpengaruh pada performansi sistem =

$\mathrm{H}{ }^{\prime}{ }_{1} \quad$ : paling sedikit ada satu $(\alpha \beta)_{\mathrm{ii}}$ tidak sama dengan nol atau terdapat interaksi antara faktor A dan B.

\section{Langkah ke-5}

Penentuan taraf keberartian uji. Taraf keberartian semakin kecil akan menunjukkan derajat ketelitian yang lebih tinggi. Pada penelitian ini akan diambil untuk nilai $\alpha=0,01$.

\section{Langkah ke-6}

Penentuan daerah kritis. Sesuai dengan nilai $\alpha=0,01$, maka untuk analisis variansi dwiarah dengan $n$ replikasi terdapat 3 (tiga) daerah kritis; ditandai dengan $\mathrm{f}_{\alpha}$ dengan daerah penolakan bila :
(a) $F_{1}>f_{\alpha}[a-1, a b(n-1)]$ atau $f_{1}>f_{\alpha 1}$
(b) $\mathrm{F}_{2}>\mathrm{f}_{\alpha}[\mathrm{b}-1, \mathrm{ab}(\mathrm{n}-1)]$ atau $\mathrm{f}_{2}>\mathrm{f}_{\alpha 2}$
(c) $F_{3}>f_{\alpha}[(a-1)(b-1), a b(n-1)]$ atau $f_{3}>f_{\alpha 3}$
Keterangan :
a : Jumlah faktor A $\left(\mathrm{n}_{1.1}\right)$
b : Jumlah faktor $B\left(\mathrm{n}_{2.1}\right)$
$\mathrm{f}_{1}$ : f hitung hipotesa h'0
$\mathrm{f}_{2}$ : f hitung hipotesa h'” 0
$\mathrm{f}_{3}$ : f hitung hipotesa h','0

\section{Langkah ke-7}

Lakukan perhitungan untuk analisis variansi dwifaktor dengan n replikasi, sebagai berikut: 


\section{JUMLAH KUADRAT}

$\mathrm{SS}_{\mathrm{r}}=\sum_{i=1}^{a} \sum_{j=1}^{b} \sum_{k=1}^{n} Y^{2} i j k-\frac{T^{2} \ldots}{a b n}$

$\mathrm{SS}_{\mathrm{A}}=\frac{\sum_{i=1}^{a} T^{2} i \ldots}{b n}-\frac{T^{2} .}{a b n}$

$\mathrm{SS}_{\mathrm{B}}=\frac{\sum_{j=1}^{b} T^{2} j \ldots}{b n}-\frac{T^{2} . .}{a b n}$

$\mathrm{SS}_{\mathrm{AB}}=\frac{\sum_{i=1}^{a} \sum_{j=1}^{b} T^{2} i j . .}{n}-\frac{\sum_{i=1}^{a} T^{2} i . .}{b n}-\frac{\sum_{j=1}^{b} T^{2} j . .}{a n}+\frac{T^{2}}{a b n}$

$\mathrm{SS}_{\mathrm{E}}=\mathrm{SS}_{\mathrm{T}}-\mathrm{SS}_{\mathrm{A}}-\mathrm{SS}_{\mathrm{B}}-\mathrm{SS}_{\mathrm{AB}}$

Keterangan :

$\mathrm{SS}_{\mathrm{T}} \quad$ : Jumlah kuadrat total (sum of square total)

$\mathrm{SS}_{\mathrm{A}} \quad:$ Jumlah kuadrat Faktor A (sum of square A)

$\mathrm{SS}_{\mathrm{B}} \quad$ : Jumlah kuadrat Faktor B (sum of square $\mathrm{B}$ )

$\mathrm{SS}_{\mathrm{AB}} \quad$ : Jumlah kuadrat interaksi (sum of square $\mathrm{AB} /$ interaction)

$\mathrm{SS}_{\mathrm{E}} \quad$ : Jumlah kuadrat Galat (sum of square error)

\section{DERAJAT KEBEBASAN}

A (Baris) $=(a-1)$

$\mathrm{B}($ kolom $)=(\mathrm{b}-1)$

$\mathrm{C}$ (Interaksi) $\quad=(\mathrm{a}-1)(\mathrm{b}-1)$

$\mathrm{D}$ (Galat) = ab(n-1)

\section{RATAAN KUADRAT}

Rataan kuadrat tiap-tiap sumber variansi adalah jumlah kuadrat masing-masing sumber variasi dibagi dengan derajat kebebasannya.
$S_{1}^{2}=\frac{S S_{A}}{a-1} \ldots(7) S_{2}^{2}=\frac{S S_{B}}{b-1} \ldots$
(8) $S_{3}^{2}=\frac{S S_{A B}}{(a-1)(b-1)} \ldots$
(9) $S^{2}=\frac{S S_{E}}{a b(n-1)}$

\section{F hitung}

Harga F hitung masing-masing sumber variasi kecuali galat, adalah rataan kuadrat masing-masing sumber variasi dibagi dengan rataan kuadrat galat (kekeliruan).

$\mathrm{f}_{1}=\frac{S_{1}^{2}}{S^{2}}$

...(11) $\mathrm{f}_{2}=\frac{s_{2}^{2}}{s^{2}} \ldots$

(12) $\mathrm{f}_{3}=\frac{s_{3}^{2}}{s^{2}}$

\section{Langkah ke-8}

Untuk memudahkan dalam pembacaannya, maka perhitungan langkah 7 dapat ditabelkan sebagai berikut : 
Tabel 12. Analisis variansi untuk percobaan Dwifaktor dengan n replikasi

\begin{tabular}{|l|l|l|l|l|l|}
\hline & $\begin{array}{l}\text { Jumlah } \\
\text { Kuadrat }\end{array}$ & $\begin{array}{l}\text { Derajat } \\
\text { Kebebasan }\end{array}$ & $\begin{array}{l}\text { Rataan } \\
\text { kuadrat }\end{array}$ & $\mathrm{F}_{\text {tabel }}$ & $\mathrm{F}_{\text {hitung }}$ \\
\hline A (baris) & $\mathrm{SS}_{\mathrm{A}}$ & $\mathrm{a}-1$ & $\mathrm{~S}_{1}{ }^{2}$ & $\mathrm{~F}_{1}$ & $\mathrm{f}_{1}$ \\
\hline $\mathrm{B}$ (kolom) & $\mathrm{SS}_{\mathrm{B}}$ & $\mathrm{b}-1$ & $\mathrm{~S}_{2}{ }^{2}$ & $\mathrm{~F}_{2}$ & $\mathrm{f}_{2}$ \\
\hline Interaksi & $\mathrm{SS}_{\mathrm{AB}}$ & $(\mathrm{a}-1)(\mathrm{b}-1)$ & $\mathrm{S}_{3}{ }^{2}$ & $\mathrm{~F}_{3}$ & $\mathrm{f}_{3}$ \\
\hline Galat & $\mathrm{SS}_{\mathrm{E}}$ & $\mathrm{ab}(\mathrm{n}-1)$ & & & \\
\hline Jumlah & $\mathrm{SS}_{\mathrm{T}}$ & $\mathrm{abn}-1$ & & & \\
\hline
\end{tabular}

\section{Langkah ke-9}

Lakukan penarikan kesimpulan uji variansi dwifaktor. Setelah perhitunganperhitungan dalam langkah di atas dilakukan, tarik kesimpulan uji berdasarkan dengan hipotesa-hipotesa pada langkah 4.

Penarikan kesimpulan uji untuk menjawab pertanyaan-pertanyan sebagai berikut :

(a) Apakah sistem manufaktur yang berbeda mempengaruhi performansi sistem atau tidak?

(b) Apakah ukuran buffer (buffer size) yang berbeda mempengaruhi performansi sistem atau tidak?

(c) Apakah ada atau tidak, interaksi antara sistem manufaktur dengan ukuran buffer terhadap performansi sistem (interaksi faktor A dan B)?

\section{Kesimpulan}

Penarikan kesimpulan atas penelitian yang telah dilakukan, apakah hipotesa awal sesuai dengan penelitian atau tidak.

\section{HASIL DAN PEMBAHASAN}

\section{A. Keluaran (output) pemodelan Simulation Manufacturing ARENA}

Tabel 13. Flowtime

\begin{tabular}{|l|l|c|c|c|c|}
\hline \multicolumn{2}{|c|}{ Sistem manufaktur } & \multicolumn{4}{|c|}{ Perlakuan (buffer size) } \\
\cline { 2 - 6 } & & 4 & 8 & 12 & 16 \\
\hline \multirow{5}{*}{ SMT } & Rep-1 & 191,66 & 243,73 & 318,79 & 298,40 \\
\cline { 2 - 6 } & Rep-2 & 353,92 & 367,66 & 388,06 & 429,39 \\
\cline { 2 - 6 } & Rep-3 & 311,07 & 268,03 & 307,35 & 265,64 \\
\cline { 2 - 6 } & Rep-4 & 230,92 & 212,84 & 277,65 & 315,60 \\
\cline { 2 - 6 } & Rep-5 & 358,54 & 748,55 & 635,44 & 487,60 \\
\cline { 2 - 6 } & Rep-6 & 242,10 & 613,42 & 338,91 & 287,24 \\
\cline { 2 - 6 } & Rep-7 & 156,43 & 232,53 & 300,93 & 292,18 \\
\cline { 2 - 6 } & Rep-8 & 249,31 & 221,33 & 516,20 & 378,32 \\
\cline { 2 - 6 } & Rep-9 & 543,50 & 505,39 & 319,48 & 247,17 \\
\cline { 2 - 6 } & Rep-10 & 226,67 & 243,00 & 267,20 & 297,42 \\
\hline \multirow{5}{*}{ JIT } & Rep-1 & 199,84 & 212,11 & 247,63 & 263,19 \\
\cline { 2 - 6 } & Rep-2 & 309,61 & 203,16 & 320,72 & 265,86 \\
\cline { 2 - 6 } & Rep-3 & 284,50 & 304,99 & 307,37 & 354,61 \\
\cline { 2 - 6 } & Rep-4 & 177,84 & 263,36 & 240,16 & 254,96 \\
\cline { 2 - 6 } & Rep-5 & 265,90 & 325,16 & 324,63 & 321,24 \\
\cline { 2 - 6 } & Rep-6 & 175,21 & 224,55 & 278,93 & 255,89 \\
\cline { 2 - 6 } & Rep-7 & 174,87 & 368,51 & 279,25 & 289,95 \\
\cline { 2 - 6 } & Rep-8 & 225,27 & 356,60 & 293,96 & 287,32 \\
\cline { 2 - 6 } & Rep-9 & 179,61 & 291,94 & 202,19 & 331,18 \\
\hline
\end{tabular}




\begin{tabular}{|l|l|l|l|l|l|}
\hline & Rep-10 & 198,73 & 226,30 & 262,93 & 273,90 \\
\hline \multirow{7}{*}{ TOC } & Rep-1 & 159,11 & 374,43 & 446,82 & 514,79 \\
\cline { 2 - 6 } & Rep-2 & 158,96 & 374,28 & 446,07 & 515,14 \\
\cline { 2 - 6 } & Rep-3 & 158,96 & 373,81 & 445,22 & 514,99 \\
\cline { 2 - 6 } & Rep-4 & 159,82 & 374,73 & 446,20 & 516,82 \\
\cline { 2 - 6 } & Rep-5 & 159,60 & 373,44 & 446,73 & 514,58 \\
\cline { 2 - 6 } & Rep-6 & 159,42 & 374,00 & 445,97 & 514,09 \\
\cline { 2 - 6 } & Rep-7 & 159,03 & 374,07 & 446,15 & 515,42 \\
\cline { 2 - 6 } & Rep-8 & 159,36 & 375,49 & 446,52 & 514,83 \\
\cline { 2 - 6 } & Rep-9 & 158,93 & 374,86 & 447,47 & 514,54 \\
\cline { 2 - 6 } & Rep-10 & 159,18 & 374,07 & 446,52 & 515,16 \\
\hline
\end{tabular}

Tabel 14. Throuhput

\begin{tabular}{|c|c|c|c|c|c|}
\hline \multirow{2}{*}{\multicolumn{2}{|c|}{ Sistem manufaktur }} & \multicolumn{4}{|c|}{ Perlakuan (buffer size) } \\
\hline & & 4 & 8 & 12 & 16 \\
\hline \multirow{10}{*}{ SMT } & Rep-1 & 4453 & 4761 & 4844 & 4879 \\
\hline & Rep-2 & 4474 & 4743 & 4842 & 4874 \\
\hline & Rep-3 & 4469 & 4755 & 4838 & 4857 \\
\hline & Rep-4 & 4453 & 4757 & 4830 & 4882 \\
\hline & Rep-5 & 4443 & 4752 & 4816 & 4874 \\
\hline & Rep-6 & 4464 & 4735 & 4844 & 4877 \\
\hline & Rep-7 & 4461 & 4757 & 4829 & 4878 \\
\hline & Rep-8 & 4481 & 4756 & 4849 & 4889 \\
\hline & Rep-9 & 4480 & 4751 & 4850 & 4878 \\
\hline & Rep-10 & 4467 & 4755 & 4846 & 4901 \\
\hline \multirow{10}{*}{ JIT } & Rep-1 & 4796 & 4916 & 4945 & 4962 \\
\hline & Rep-2 & 4812 & 4919 & 4952 & 4962 \\
\hline & Rep-3 & 4802 & 4918 & 4940 & 4956 \\
\hline & Rep-4 & 4803 & 4920 & 4942 & 4957 \\
\hline & Rep-5 & 4796 & 4907 & 4937 & 4950 \\
\hline & Rep-6 & 4810 & 4924 & 4945 & 4957 \\
\hline & Rep-7 & 4799 & 4904 & 4936 & 4951 \\
\hline & Rep-8 & 4814 & 4911 & 4948 & 4956 \\
\hline & Rep-9 & 4802 & 4914 & 4941 & 4961 \\
\hline & Rep-10 & 4802 & 4910 & 4945 & 4958 \\
\hline \multirow{10}{*}{ TOC } & Rep-1 & 4984 & 4994 & 4997 & 4996 \\
\hline & Rep-2 & 5007 & 4999 & 4987 & 5003 \\
\hline & Rep-3 & 4968 & 4983 & 5010 & 4997 \\
\hline & Rep-4 & 4970 & 5005 & 5006 & 4981 \\
\hline & Rep-5 & 4990 & 5009 & 4991 & 5001 \\
\hline & Rep-6 & 4979 & 5000 & 5004 & 5008 \\
\hline & Rep-7 & 5011 & 5001 & 5000 & 4994 \\
\hline & Rep-8 & 4985 & 4990 & 5013 & 5003 \\
\hline & Rep-9 & 4983 & 4995 & 4998 & 5000 \\
\hline & Rep-10 & 4991 & 5007 & 5006 & 4998 \\
\hline
\end{tabular}

\section{B. Analisis Variansi}

Setelah dilakukan perhitungan analisis dwifaktor terhadap hasil running program pemodelan sistem manufaktur didapat kesimpulan uji statistik sebagai berikut: 
Tabel 15. Hasil analisis variansi dwifaktor untuk 10 replikasi

\begin{tabular}{|l|l|l|l|l|l|}
\hline \multicolumn{2}{|c|}{ Performansi } & $\mathbf{F}_{\text {hitung }}$ & $\mathbf{F}_{\text {tabel }}$ & Kesimpulan & \multicolumn{1}{|c|}{ Keterangan } \\
\hline \multirow{3}{*}{ Flowtime } & H'o & 18,66 & 4,81 & Tolak H'o & Sistem manufaktur berpengaruh \\
\cline { 2 - 6 } & H'o & 23,39 & 3,97 & Tolak H'’ & Total inventory buffer berpengaruh \\
\cline { 2 - 6 } & H'’o & 8,49 & 2,97 & Tolak H'’o & Terdapat interaksi faktor \\
\hline \multirow{3}{*}{$\begin{array}{l}\text { Throughp } \\
\text { ut }\end{array}$} & H'o & 8951,77 & 4,81 & Tolak H'o & Sistem manufaktur berpengaruh \\
\cline { 2 - 6 } & H'o & 2898,31 & 3,97 & Tolak H'’o & Total inventory buffer berpengaruh \\
\cline { 2 - 6 } & H'’o & 1063,65 & 2,97 & Tolak H'’’o & Terdapat interaksi faktor \\
\hline
\end{tabular}

Tabel diatas mengatakan penolakan atas semua hipotesa uji, hal ini berarti bahwa :

1. Besar performansi flowtime dan throughput dipengaruhi oleh sistem manufaktur

2. Besar performansi flowtime dan throughput juga dipengaruhi total inventory buffer

3. Sistem manufaktur dan total inventory buffer berinteraksi mempengaruhi besar performansi flowtime dan throughput

C. Analisis performansi pada ketiga sistem manufaktur yang diujicobakan

Performansi yang diukur dalam penelitian ini adalah flowtime dan throughput yang didapat dari hasil running simulasi sebanyak 10 replikasi untuk masing-masing kondisi penelitian. Tabel berikut ini memperlihatkan performansi flowtime dan throughput untuk masing-masing sistem manufaktur yang diujicobakan :

\section{Rata-rata Flowtime}

Tabel 16. Flowtime masing-masing sistem manufaktur

\begin{tabular}{|l|c|c|c|}
\hline \multirow{2}{*}{} & \multicolumn{3}{|c|}{ SISTEM MANUFAKTUR } \\
\cline { 2 - 4 } & SMT & JIT & TOC \\
\hline Buffer size $=4$ & 286,44 & 219,14 & 159,24 \\
\hline Buffer size $=8$ & 365,65 & 277,67 & 374,32 \\
\hline Buffer size $=12$ & 367,00 & 275,78 & 446,37 \\
\hline Buffer size $=16$ & 329,90 & 289,81 & 515,04 \\
\hline Average & $\mathbf{3 3 7 , 2 5}$ & $\mathbf{2 6 5 , 6 0}$ & $\mathbf{3 7 3 , 7 4}$ \\
\hline
\end{tabular}

Nilai rata-rata flowtime dari penelitian diatas menunjukkan bahwa rata-rata flowtime tertinggi terjadi pada sistem TOC $(373,74)$, kemudian tertinggi kedua adalah SMT $(337,25)$ dan yang terendah adalah terjadi pada sistem JIT $(265.60)$. Untuk nilai flowtime terendah pada sistem manufaktur JIT sangatlah sesuai dengan filosofi JIT yaitu eliminate of waste dimana dalam penelitian ini upaya yang dilakukan untuk mewujudkan filosofi di atas adalah dengan cara menurunkan variasi waktu proses pada setiap stasiun kerja (dalam sistem JIT) sehingga akan tercipta lintasan produksi yang seimbang yang dapat mencegah terjadinya bottleneck dalam sistem.

\section{Rata-rata Throughput}

Tabel 17. Throughput masing-msing sistem manufaktur

\begin{tabular}{|l|c|c|c|}
\hline \multirow{2}{*}{} & \multicolumn{3}{|c|}{ SISTEM MANUFAKTUR } \\
\cline { 2 - 4 } & SMT & JIT & TOC \\
\hline Buffer size $=4$ & 4464,50 & 4803,60 & 4986,80 \\
\hline Buffer size $=8$ & 4752,20 & 4914,30 & 4998,30 \\
\hline Buffer size $=12$ & 4838,80 & 4943,10 & 5001,20 \\
\hline Buffer size $=16$ & 4878,90 & 4957,00 & 4998,10 \\
\hline Average & $\mathbf{4 7 3 3 , 6 0}$ & $\mathbf{4 9 0 4 , 5 0}$ & $\mathbf{4 9 9 6 , 1 0}$ \\
\hline
\end{tabular}


Apabila kita tinjau kembali performansi yang dapat dicapai dari ketiga sistem manufaktur, kita dapat menyimpulkan bahwa sistem manufaktur TOC dengan total inventory buffer $=4$ merupakan suatu sistem yang mampu menghasilkan nilai rata-rata flowtime terendah dan juga mampu menghasilkan nilai rata-rata throughput yang tertinggi untuk ukuran total inventory buffer maksimum=4 dari ketiga sistem manufaktur di atas.

Sementara apabila total inventory buffer TOC $>4$, nilai rata-rata flowtime yang terjadi akan sangat tinggi (tertinggi dari sistem manufaktur lainnya) sehingga pada TOC, penambahan ukuran buffer tidaklah memberikan keuntungan, baik dari segi performansi flowtime maupun throughput karena hanya dengan ukuran buffer $=4$ saja, TOC mampu menghasilkan nilai rata-rata flowtime terendah dan nilai rata-rata throughput tertinggi dari sistem manufaktur lainnya.

\section{KESIMPULAN DAN SARAN}

\section{A. Kesimpulan}

Penelitian yang telah dilakukan dalam upaya mengukur dan menganalisa performansi yang ditimbulkan oleh ketiga sistem manufaktur (SMT, JIT, TOC) yang dicobakan dalam lingkungan industri single product flow shop yang dipengaruhi variasi total inventory buffer yang diterapkan, menghasilkan kesimpulan bahwa jenis sistem manufaktur yang dicobakan ternyata mempengaruhi besarnya performansi nilai rata-rata flowtime dan nilai rata-rata throughput dari sistem. Variasi total inventory buffer yang digunakan pun ikut berpengaruh terhadap besarnya performansi nilai rata-rata flowtime dan nilai rata-rata throughput yang terjadi. Selain itu terbukti bahwa interaksi antara sistem manufaktur dengan total inventory buffer, akan mempengaruhi besarnya performansi nilai rata-rata flowtime dan nilai rata-rata throughput dari sistem.

Nilai rata-rata flowtime akan bertambah besar seiring dengan bertambahnya ukuran total inventory buffer yang digunakan dalam masing-masing sistem manufaktur. Nilai rata-rata throughput-pun akan bertambah besar seiring dengan bertambahnya ukuran total inventory buffer yang digunakan dalam masing-masing sistem manufaktur. Rata-rata flowtime terendah untuk semua total inventory buffer, terjadi pada sistem manufaktur JIT $(265,60)$, kemudian $\operatorname{SMT}(337,25)$, dan berikutnya adalah TOC $(373,74)$

Dari semua penelitian dan analisa yang telah dilakukan, ternyata didapat suatu rumusan penting bahwa sistem manufaktur yang terbaik untuk diterapkan dalam lingkungan industri single product flow shop adalah sistem manufaktur TOC dengan ukuran total inventory buffer maksimum sebesar 4, karena pada formasi sistem seperti inilah didapat performansi sistem terbaik, yaitu rata-rata flowtime terendah dan rata-rata troughput tertinggi

Terakhir kesimpulan yang dapat diambil dari penelitian di atas adalah filosofi sistem manufaktur tradisional tidaklah memberikan keuntungan yang lebih jika dibandingkan dengan sistem manufaktur JIT dan TOC. Selanjutnya TOC mempunyai performansi di atas JIT pada performansi rata-rata troughput walaupun kadang-kadang TOC mempunyai rata-rata flowtime yang lebih tinggi dari SMT dan JIT, yang mana hal ini sebenarnya menjadi atribut bahwa TOC membutuhkan lebih sedikit inventory dibandingkan dengan sistem manufaktur lainnya.

\section{B. Saran}

Bagi para peneliti berikutnya, apabila akan melakukan penelitian lanjutan dapat melakukan peningkatan kompleksitas lingkungan industrinya dengan menambahkan beberapa masalah berupa:

1. Memasukkan faktor breakdown machine dan maintenance machine ke dalam stasiun kerja (mesin-mesin dalam lini produksi)

2. Produk yang dihasilkan merupakan tipe multiple product 
3. Jenis entity yang akan diproses berjumlah lebih dari 1 jenis

4. Memasukkan faktor inspeksi ke dalam stasiun kerja

5. Memperhatikan faktor scrapt dan rework

\section{Daftar Pustaka}

[1] Cook, David P., 1994, A Simulation of Traditional, JIT and TOC Manufacturing Systems in a Flow Shop with Bottleneck, PIM Journal, First Quarter, pp. 73-78

[2] Conway, Richard., Maxwell, William., McClain, John O., 1998, The Role of Work in Process Inventory in Serial Production Lines, Operation Research, pp.229-242

[3] Yanradee, Pisal., Dr., 1994, "Performance Analysis of Push, Pull, and Detail Scheduling Systems in an Environment of Flow shop", Worksims '94 Nov. 9-11

[4] System Modelling Corportion,1994, ARENA Template Reference Guided

[5] Ma'ruf Anas, 1995, Mempelajari Metoda dan Karakteristik Operasional OPT menggunakan Simulasi Komputer, Tugas Akhir, Jurusan Teknik Industri ITB, Bandung

[6] Putranto, Utomo Dwi, 1996, Penempatan Buffer di 3 Stasiun Serial Lines yang Tidak Seimbang, Tugas Akhir, Jurusan Teknik Industri UNPAS, Bandung 